$30^{\circ} \mathrm{C}$., on alatæ from laboratory cultures and natural infestations of broadbeans (Vicia faba L.).

The aphids were given flight exercise by attaching them by the thorax to small pins with water-colour paint, and also by permitting untethered flight in the greenhouse. In this way it was shown that a very short flight of an average of about 20 sec. was sufficient to result in the changed behaviour when the aphids were returned to their host plants. The change could be induced by longer periods of activity other than flight, as when the aphids were kept in the light for several hours in a narrow glass tube in which they were able to crawl but unable to fly.

Aphids alighting on a host plant after sufficient flight wander about for several minutes and whether they stay or leave is influenced by the host suitability. Flown aphids placed on highly suitable hosts $(6 \mathrm{~cm}$. high broadbean seedlings) settled and remained there until they had lost the ability to fly ; on less suitable hosts (isolated mature broadbean leaves) they took off again. Aphids placed on young plants of broadbean 1 metre high showed a considerable variation in behaviour after wandering; a few remained but most of them took off again, this agreeing with the field observations of other workers ${ }^{1,4}$.

Parturition occurs soon after the aphids settle down on seedlings after flight, or are confined after flight on mature leaves in the dark; its initial rate is influenced by the state of development of the embryos and not by the quality of the host ${ }^{5}$. Nor is it necessary for the aphids to feed for them to stay and bear young, contrary to the assumption of Kennedy and Booth ${ }^{6}$. When unflown aphids are confined on host plants by darkness from flight maturity, embryonic development continues but no larvæ are born for two days or more, although several hours after reaching flight maturity the ovaries contain 8-12 fully formed embryos. Such aphids when flown commenced to bear young within an hour of settling, and a number of larvæ were then born at half-hourly intervals; an average of $9 \cdot 0 \pm 0 \cdot 24$ larvæ were born overnight $(n=77)$. Aphids flown as soon as they reached flight maturity gave birth to an average of only $3 \cdot 4 \pm 0 \cdot 20$ larvæ overnight $(n=50)$. Anything, therefore, which delays the initial take-off of the aphids from their parent host plant will help to reduce the length of their flying life by increasing the number of larvæ born in the first batch and so hastening the processes leading to the autolysis of the flight muscles?

Young aphids which have alighted on an unsuitable host or have been disturbed while feeding on a suitable host may take off again, and a further short flight is necessary before they will settle down to feed and reproduce.

This work will be published in detail elsewhere.

I am indebted to Dr. C. G. Johnson and Dr. J. S. Kennedy for reading this communication in draft.

Bruce Johnson

Department of Entomology, Rothamsted Experimental Station, Harpenden, Herts. Jan. 26.

${ }^{1}$ Müller, H. J., Züchter, 23, 176 (1953).

${ }^{2}$ Moericke, V., "Zur Lebensweise der Pfirsichlaus (Myzodes persicae Sulz.) auf der Kartoffel", thesis, Univ. of Bonn (1941).

${ }^{3}$ Müller, H. J., and Unger, K., Züchter, 22, 206 (1952).

4 Kennedy, J. S., Nature, 165, 1024 (1950).

- Kennedy, J. S., and Booth, C. O., Ann. App. Biol., 38. 25 (1951)

- Kennedy, J. S., and Booth, C. O., Ann. App. Biol., 37, 451 (1950).

? Johnson, Bruce, Nature, 172, 813 (1953).

\section{The Marshes of the Medway Estuary in Romano-British Times}

THe view has long been held that the RomanoBritish pottery and clay fire-bars which occur at various levels in the Scrobicularia Clay (that represents the bulk of the estuarine deposits which compose the marsh) constitute the output and appurtenances of contemporary potters' kilns which had been sited somewhere on the marsh.

The makers' stamps on the pottery cover a period ranging from the middle of the first century A.D. to the third quarter of the second century ; though the greater number of the stamps fall within the HadrianAntonine phase, namely, between A.D. 117 to A.D. 161 .

The present Ordnance Survey maps (scale 6 in. to 1 mile) of the area in question set across many of the saltings the following legend: "Roman Potteries (Site of)". Indeed, that of "Kent" (Sheet XX, N.E. Edition, 1908) shows no less than four such sites.

As the result of twenty-five years study of the deposits of the Upchurch Marsh, I write to suggest that this area could not possibly have supported a Romano-British pottery-making industry. The evidence upon which this suggestion is founded is twofold-one geological, the other archæological. There is overwhelming proof that shortly after the commencement of the second century A.D. the sea had obtained complete control over the whole district and that Scrobicularia Clay had been universally deposited to the level of $5 \mathrm{ft}$. above O.D.

At this stage Romano-British man occupied the intertidal surface of the marsh-clay for the purpose of making salt. This industry is reflected in the occurrence over widespread areas of a specific deposit containing briquetage, clay fire-bars which were required for the process of salt-making, broken pottery and animal bones.

Over this accumulation of refuse-which varies in thickness from 6 in. to $3 \mathrm{ft}$.- the sea continued its deposition of marsh-clay up to a height of $11 \mathrm{ft}$. above O.D., which forms the highest level of the present-day salting surface.

A detailed description of the various archæological horizons which occur in these estuarine deposits will be furnished in a paper to be read later in the year. J. P. T. BURChELL

Falcon Cottage, Fawke Common, Sevenoaks, Kent. Jan. 16.

\section{Zoological Nomenclature}

Notice is hereby given that the International Commission on Zoological Nomenclature has under consideration the following case involving the possible use of its plenary powers : Caenisites Buckman, 1925 (Class Cephalopoda, Order Ammonoidea), proposed suppression of. Full particulars of this case are given in Part 12 of volume 6 of the Bulletin of Zoological Nomenclature.

Any comments on the above case should be sent to me as soon as possible and, in any event, should be dispatched in time to reach me not later than August 26, 1954, when voting on this case will begin.

Francis Hemming

(Secretary to the International Commission on Zoological Nomenclature)

28 Park Village East,

Regent's Park, London, N.W.1. 